Ekonomia - Wroclaw Economic Review 25/4 (2019)

Acta Universitatis Wratislaviensis

No 3949

DOI: $10.19195 / 2658-1310.25 .4 .6$

Katarzyna Szalonka

ORCID: 0000-0001-7290-6408

University of Wrocław

katarzyna.szalonka@uwr.edu.pl

Piotr Stańczyk

ORCID: 0000-0003-0124-2936

Wrocław University of Economics

piotr.stanczyk@ue.wroc.pl

\title{
Consumption of sustainable medications and its impact on health
}

Date of submission: 10.09.2018; date of acceptance: 22.10 .2019

JEL Classification: D9, I12

Keywords: consumption, medications

Abstract

Consumption of sustainable medications and its impact on health

Sustainable consumption of medicines is medically justified medicine consumption, indispensable in the treatment process, which contributes to the quality of life of the patient and extends the patient's life resulting from the doctor's recommendations and verified by the pharmacist (elimination of medicine interactions).

The aim of this paper is to analyze differences in the level of medicines consumption in Poland and in the wider world, and its impact on life expectancy and health status. There is a large variation in the per capita medicine intake in certain countries. The following hypothesis was formulated in the paper: the consumption of medicines is not related to the health and longevity of the inhabitants.

The article is based on secondary research and a statistical analysis of medicine consumption in selected countries in the years 2015-2018. Also presented are the results of research regarding the consumption of medicines in terms of quantity and value in Poland against the background of selected countries and also in regional location in the context of socio-economic conditions. 


\section{Introduction}

Since the mid-1980s, a policy of sustainable medicines consumption has been promoted through the implementation of pharmaceutical care. It has been scientifically proven that abnormal consumption is the cause of 5\% of deaths in Poland every year, and the costs of treatment due to non-compliance with therapeutic recommendations were estimated at the level of the annual budget of Basic Healthcare (PLN 6 billion) (Kardas, 2010). Sustainable consumption of medicines is medically justified medicine consumption, indispensable in the treatment process, which contributes to the quality of life of the patient and extends the patient's life resulting from the doctor's recommendations and verified by the pharmacist (elimination of medicines interactions). The aim of this paper is to analyze the differences in the level of medicines consumption in Poland and in the wider world and its impact on life expectancy and health status. There is a large variation in per capita medicines intake in certain countries. The following hypothesis was formulated in the paper: the consumption of medicines is not related to the health and longevity of the inhabitants.

The subject scope of the article included medicine consumption in selected countries in 2015-2018 and in Poland against the background of European countries and by voivodship. The source of empirical data were data on the size and value of selected drugs, obtained from the IMS database and data on selected socio-economic conditions, downloaded from the Eurostat online database and the CSO BDL database.

\section{The principles of the pharmaceutical market}

The pharmaceutical market is strongly regulated by legal standards, including pharmaceutical law, the act on pharmacies, on health-care services financed from public funds, and others. Regulations concern the principles of medicines production, their distribution to wholesalers and pharmacies, and the method of classification and ordination. On the supply side there are producers with Polish capital (e.g. Polpharma, Galena), foreign ones (GlaxoSmithKline), distributors (e.g. Neuca, Farmacol) and pharmacies (about 14,000). On the demand side, there are patients as well as hospitals and outpatient clinics. These are the entities that report the demand for medicines. The specificity of the pharmaceutical market is the ordination (recommending) by doctors of a medicinal product for consumption - and the payer is the patient and/or the National Health Fund (NHF). This means that the person choosing the product does not pay for it. The consumer, who has no knowledge of the product, pays, and he is not able to independently decide on the choice of medicines. There is, therefore, no demand-supply coupling. The reason is an intermediary (a doctor or a pharmacist) who should recommend 
the medicine best suited to the patient's needs (Fig. 1). However, this decision of a specialist is rarely correlated with the knowledge about economic opportunities to finance a patient's purchase.

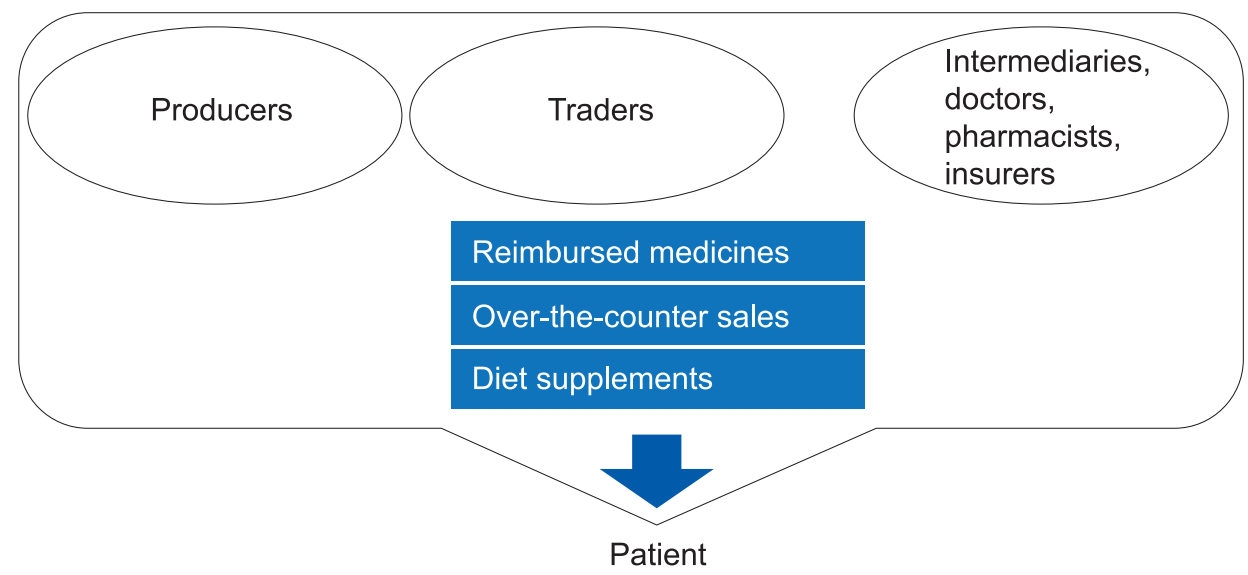

Figure 1. Model of the pharmaceutical market

Source: authors' own work.

The subject of the transaction are medicines and dietetic foods. Medicines are defined as substances in the form of tablets, suppositories, syrup, ointments, injections, drip - used to fight disease as well as preventing it. Their specificity is the necessity to apply procedures designated and controlled by the Main Pharmaceutical Inspectorate, the National Medicines Institute and the Ministry of Health.

There are many medicine classification criteria in the pharmaceutical literature. The article will only present a criterion applicable in the market analysis. One can distinguish:

- ethical medicines - prescribed by a doctor and issued upon presentation of a prescription $(\mathrm{Rx})$,

- refunded ethical medicines (partly or entirely financed by the NHF) and not refunded (purchase of a medicine financed by the patient),

- OTC (over-the-counter) medicines, medicines that can be bought at a pharmacy without a prescription,

- original medicines (medicines with a new active substance, which are patented by the creator, a special feature is their high price resulting from high implementation costs),

- generic medicines (medicines whose active substance has been restored from patents after the end of the protection period, characterized by a much lower price than the original ones),

- medicines - supplements - dietetic foods (preparations mistakenly identified by patients as medicines that the manufacturer introduces to the market by referring to the Chief Sanitary Inspectorate). 
To sum up the classification above, the pharmaceutical products offered are characterized by a life-cycle phase (1st original and 2nd generation) and manufacturing and registration procedures (1. medicines - manufactured based on procedures compliant with pharmaceutical law and 2. supplements - reported to the Chief Sanitary Inspectorate as food).

\section{The rationality of medicines consumption and the profitability of the pharmaceutical industry}

The demand for medicines in Poland and in the world has a growing tendency and guarantees stability and profitability for pharmaceutical companies. This is due to the fact that the medicine is considered by the patient to be a life-saving and health-saving product. It becomes a priority in consumer choices. In addition, in many countries demand is stimulated by the advertising of medicines. In Poland, the advertising of OTC medicines and supplements is permitted. In the US, ethical medicines are also advertised. The demand for medicines is stimulated by marketing communication, affecting the increase in the sales of medicines. One can assume that the more intensive the advertisement, the higher the medicine sales. It turns out that the patient, under the influence of the advertisement, generates demand for the medicine, makes independent decisions on the purchase of a pharmaceutical (Table 1).

Table 1. The impact of advertising on medicine sales — Polpharma, Metafen*

\begin{tabular}{|l|c|c|c|}
\hline \multicolumn{1}{|c|}{ Years } & $\begin{array}{c}\text { Number of } \\
\text { packages sold (pcs) }\end{array}$ & Dynamics pcs (\%) & $\begin{array}{c}\text { Advertising expenditure } \\
\text { (PLN mln) }\end{array}$ \\
\hline 2010 & 273,835 & $1,078.0$ & - \\
\hline 2011 & 160,780 & 58.7 & - \\
\hline 2012 & $1,427,961$ & 888.1 & 30.8 \\
\hline 2013 & $1,280,740$ & 89.7 & 17.6 \\
\hline 2014, October & 1,156701 & 90.3 & 34.9 \\
\hline
\end{tabular}

* A Wholesale-pharmacies, implemented in 2006.

Source: Szalonka and Krajewska-Smardz (2015, 1077-1082).

The supplying entities pursue their own business goals and the patient consumes them after purchasing medicines. The process of consumption of more medicines simultaneously (polypragmasy) contributes to the interaction, which can lead to poisoning of the body. This phenomenon is quantitatively and value-poorly characterized. Therefore, at the end of the 20th century, C. Hepler and L. Strand (1990) developed a concept for monitoring the process of medicines consumption. The project was named internationally as Pharmaceutical Care and was implemented in many countries. It consists in monitoring the consumption of medicines 
by pharmacists. The point is that the economic factor (the pursuit of maximization of profit) does not destroy the health of patients, but saves them. There are various programs to promote pharmaceutical care in Poland, Europe and the world. One of the programs, "Together for health", exposes the conscious attitude of the patient consuming medicines (see Fig. 2).

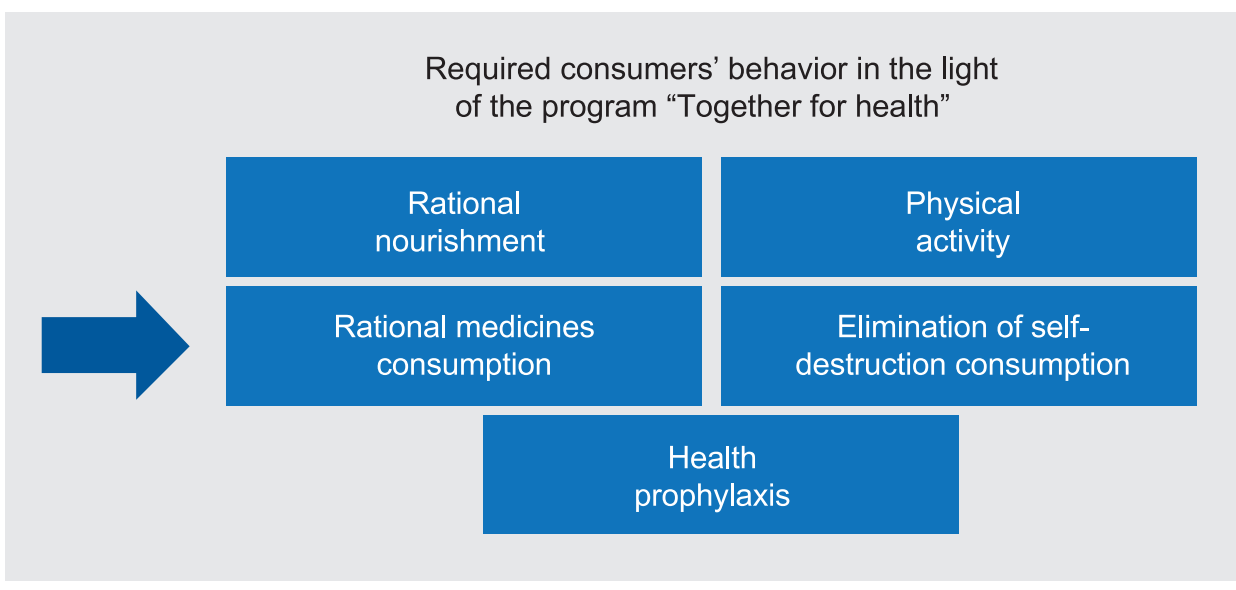

Figure 2. Rational consumption of medicines in the program "Together for health"

Source: Szalonka $(2014,199-208)$.

\section{An analysis of medicines sales in Poland}

One of the basic measures of availability of medicines for patients is the number of patients per pharmacy. A large number of pharmacies potentially increase the availability of the medicine and also the access to professional knowledge a pharmacist who should advise and control the process of medicine consumption. In Europe and in the world, the number of pharmacies varies (Fig. 3). Poland is characterized by a large number of pharmacies - 14,700 (2,700 people per pharmacy) in 2019. This number has been maintained for 5-6 years and due to changes in the law on regulating the operation of pharmacies, from 2012 it experienced a downward trend. A new pharmacy can be set up only by a pharmacist under any indicated legal form (the project is popularly referred to as "Pharmacy for the pharmacist").

In addition, when setting up pharmacies, there is a geographical-demographic criterion - one cannot set up a pharmacy if in a given municipality there are fewer than 3,000 inhabitants per pharmacy, and the distance between neighboring facilities must be at least 500 meters (Nowelizacja ustawy..., 2017).

In terms of value, medicines sales in Poland are systematically growing in all medicines categories (Table 2). 


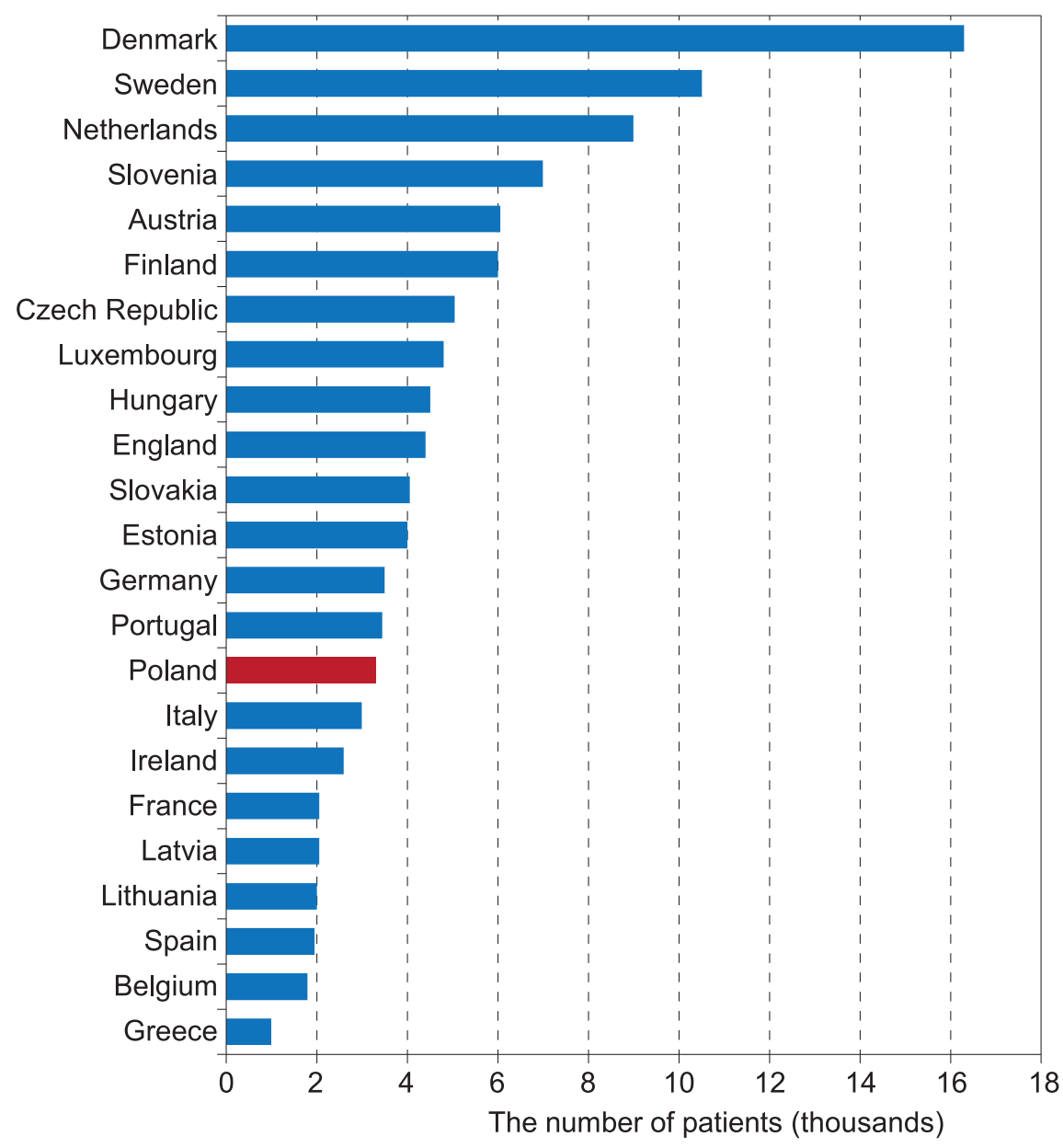

Figure 3. The number of patients per pharmacy in selected countries in 2016

Source: Die Apotheke. Zahlen. Daten. Fakten (2016).

Table 2. Value sales of a statistical pharmacy in 2017 and 2018

\begin{tabular}{|l|r|c|c|c|}
\hline \multicolumn{1}{|c|}{ Statistical pharmacy } & \multicolumn{4}{c|}{ Average sales of a statistical pharmacy } \\
\hline \multicolumn{1}{|c|}{ Key market segments } & 2018 & 2017 & Change & Trend \\
\hline Reimbursed medicines (Rx) & 817 & 778 & 39 & $5.0 \%$ \\
\hline Fully-paid medicines (Rx) & 504 & 484 & 20 & $4.1 \%$ \\
\hline Over-the-counter sales (OTC) & 982 & 922 & 60 & $6.5 \%$ \\
\hline Total sales & 2,320 & 2,200 & 120 & $5.5 \%$ \\
\hline
\end{tabular}

Source: Aptekarz Polski (2019).

Total sales year-over-year in 2018 increased by 5.5\% as compared to 2017. The average pharmacy margin is 25\% (Aptekarz Polski, 2019). 


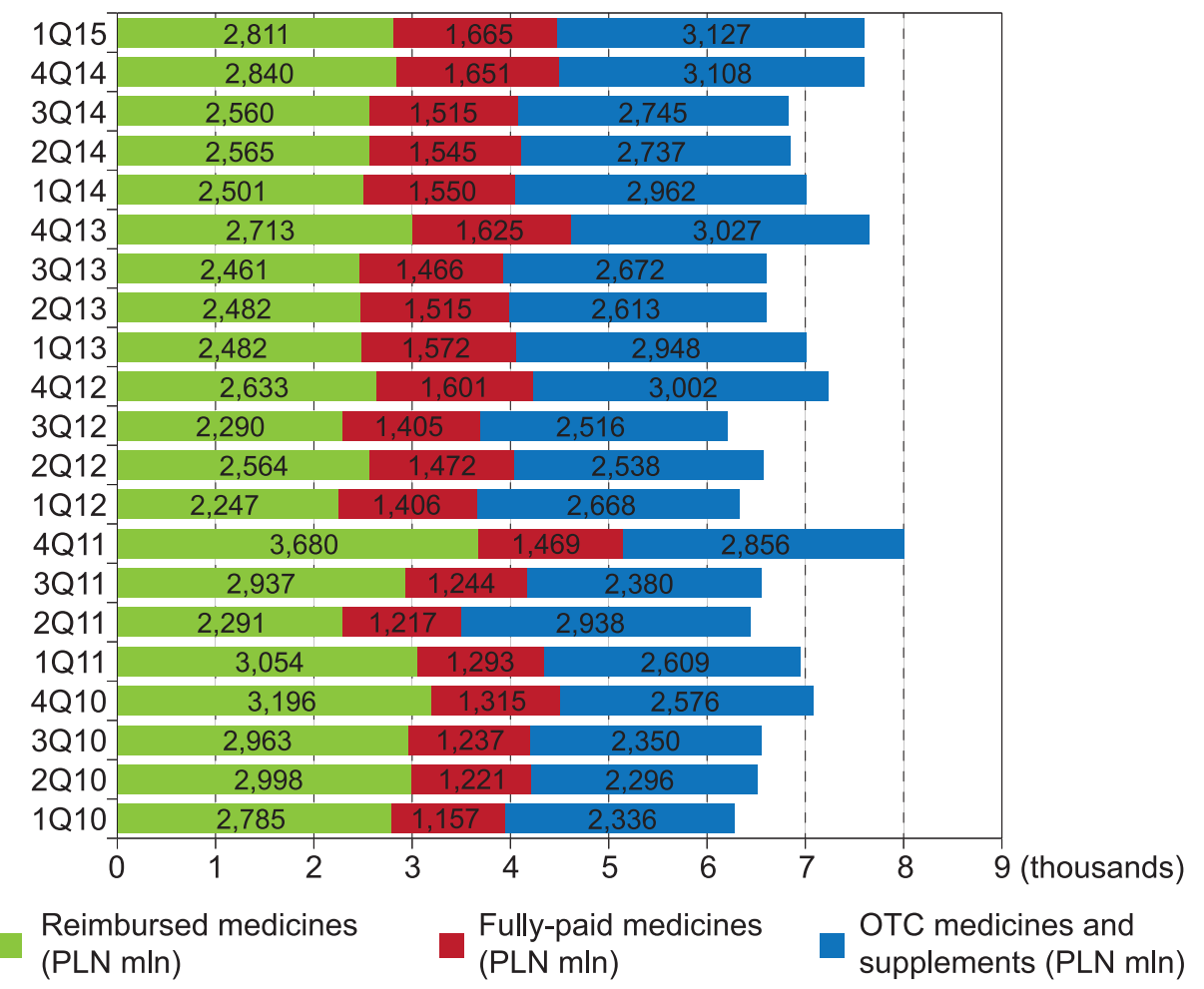

Figure 4. Structure of the Polish pharmaceutical market in the years 2010-2015 (shown in quarters)

Source: authors' own work based on data from Pharma Expert.

The analysis of the sales structure of medicines in the years 2010-2015 clearly shows that sales of OTC medicines are increasing - by comparing the fourth quarter of 2010 with the fourth quarter of 2015 , sales increased by $21.4 \%$. This means that the self-healing process is increasing. Poles spend more on OTC medicines and supplements than on prescription medicines (Table 1 and Fig. 4). This means that patients themselves decide to consume medicines, based on information obtained from advertisements - without substantive supervision. The pharmacy should be a place for professional care and substantive support in order to minimize the risk of loss of life and health caused by incorrect consumption of pharmaceuticals.

\section{The impact of medicines consumption on the health and life of patients}

For the purposes of this article, data on the quantity of medicines sold in selected European countries, Asia, North and South America were collected and information on life expectancy was generated from the Eurostat database available online. 
The study adopted a simplification that all other variables (the price of medicine, environment, lifestyle, access to health care and its organization, genetic factors) in all countries have the same impact on the consumption of medicines and the life expectancy of residents.

The data obtained on the quantitative consumption of medicines (number of packages per capita) are strongly differentiated - from more than 45 packages per person in France and 40 in Greece to 9 in Japan and 5 in China (Fig. 5). Po-

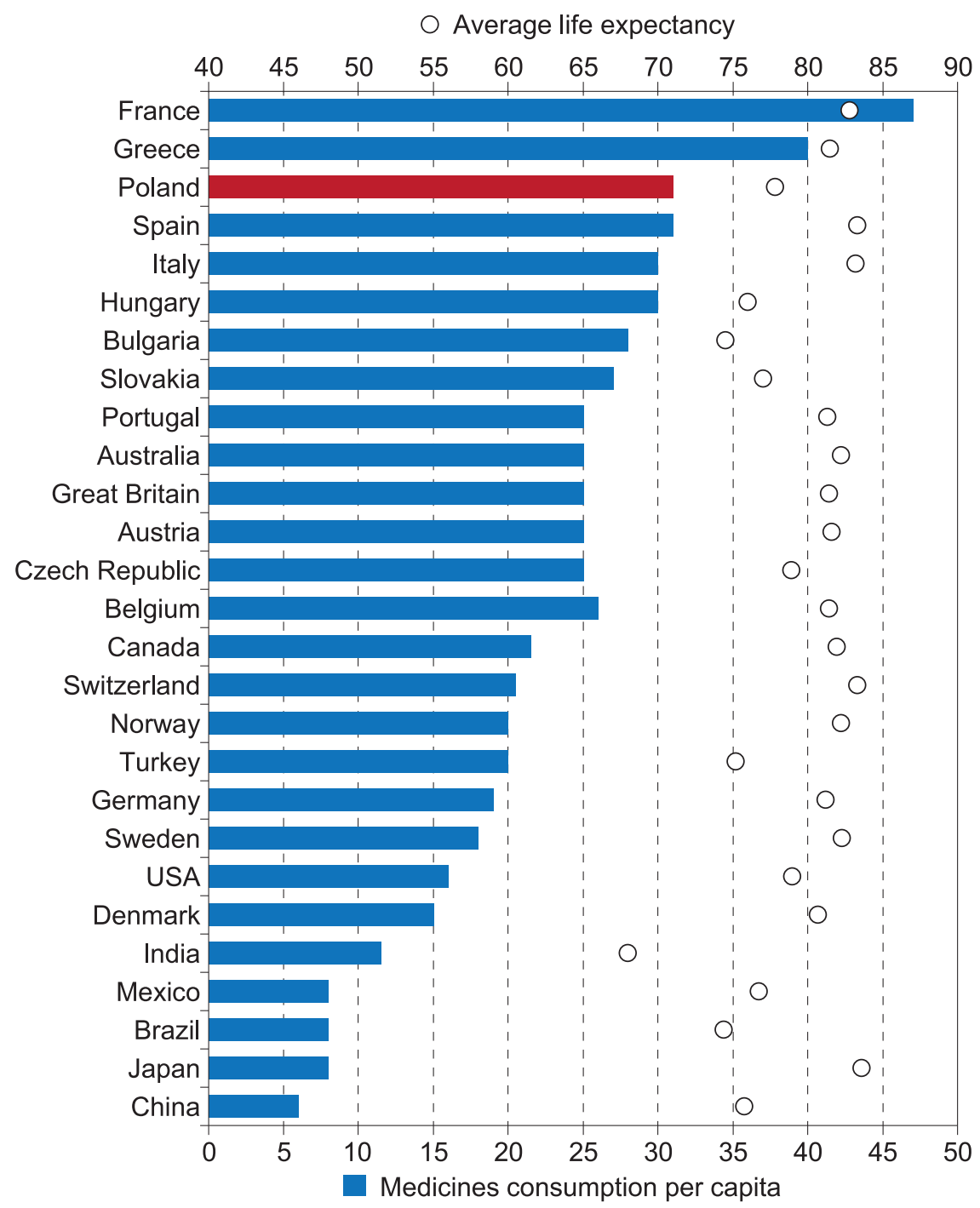

Figure 5. Quantitative view of medicines consumption versus life expectancy in selected countries in 2016

Source: authors' own work based on data from IMS HEALTH, CIA and Eurostat database. 
O

Deaths from cancer and diseases of the circulatory system per 100 thousand inhabitants

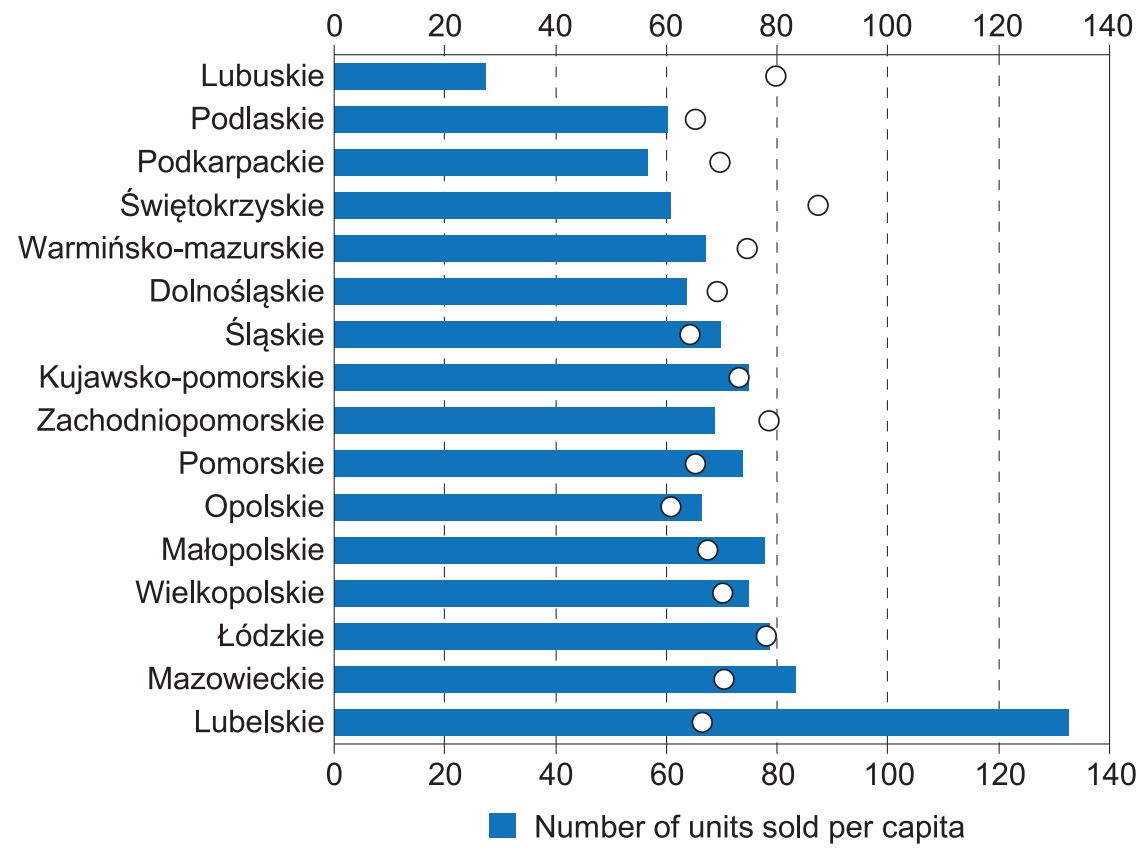

Figure 6. Quantitative view of the consumption of medicines containing the active substance ibuprofenum versus health status by voivodships in 2016

Source: authors' own work based on data from the IMS HEALTH, GUS and Eurostat database.

land is third in this ranking (34 packages). It is difficult to indicate the reasons for such diversity. It can be assumed that the largest impact on the amount of purchased pharmaceuticals is the respective health policies in force in each country, the organization of medical care, medicine prices, purchasing power, as well as the marketing communications of pharmaceutical companies. From Figure 6 one can conclude that there is no relationship between the size of medicine consumption and the average life expectancy. By analogy, on the basis of the comparison of GDP per capita and the volume of medicines consumption, it can be assumed that there is no correlation between these characteristics. It does not affect GDP per capita. In France in 2017, GDP per capita amounted to $\$ 42,568$, in Japan it was $\$ 48,557$ and in Poland it was almost half, at $\$ 27,216$. Although the GDP of France and Japan was at a similar level, the amount of medicines bought by the Japanese was 4.5 times lower. ${ }^{1}$

1 The authors do not have data that would allow the PPP indicators to be compiled for the medicines themselves. Hence, there is no analysis regarding the impact of medicines' prices on consumption. If such data were obtained - they would not provide reliable results due to different legal regulations regarding the financing of consumption in individual countries and in the distinc- 


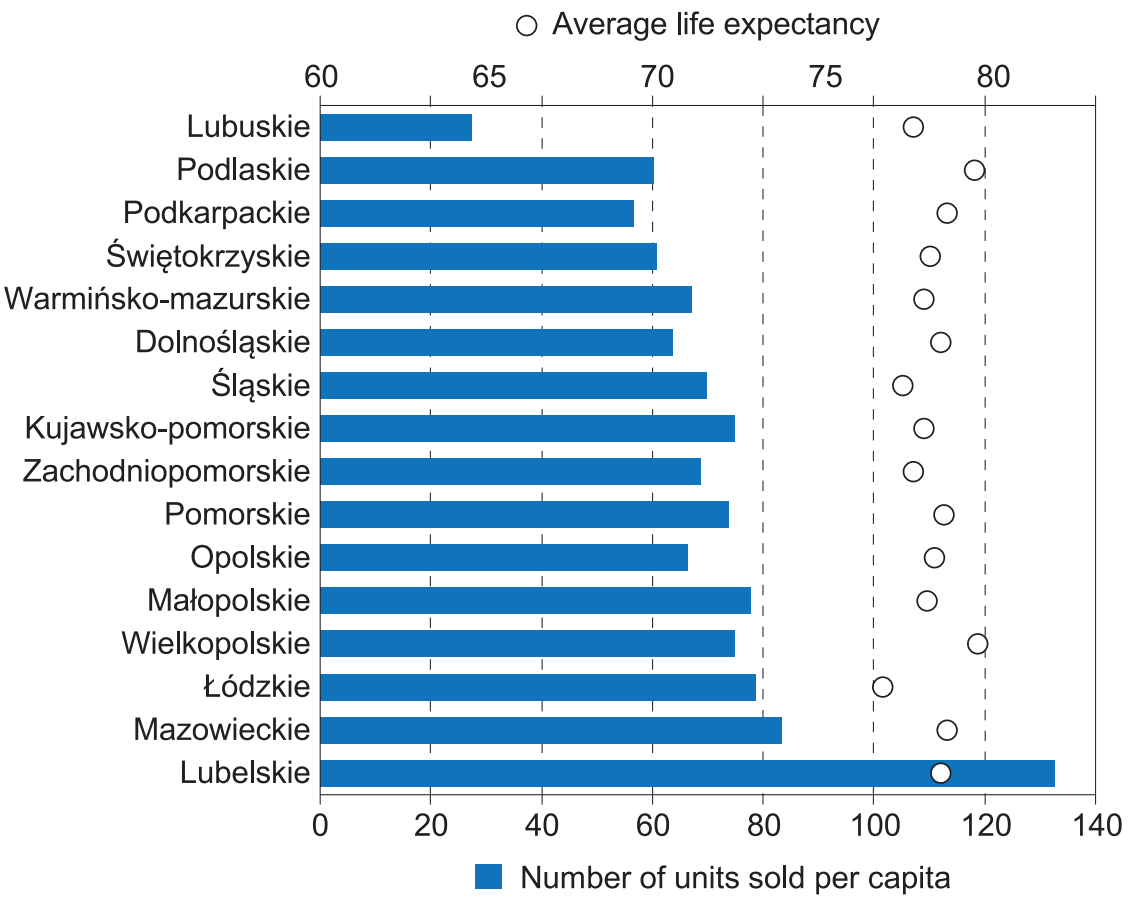

Figure 7. Quantitative view of the consumption of medicines containing the active substance ibuprofenum versus life expectancy by voivodships in 2016

Source: authors' own work based on data from the IMS HEALTH, GUS and Eurostat database.

We also carried out an analysis of the consumption of selected medicines, including a pharmaceutical with the active substance ibuprofenum (Fig. 7) from the group of analgesics, characterized by the highest consumption at the level of provinces in Poland. The results of the analysis also indicate in the spatial system the lack of dependence between the sales volume of the pharmaceutical and the active substance ibuprofenum in relation to the number of inhabitants, the size of average life expectancy, and the health status described by the death rates due to cancer and cardiovascular system. This is also confirmed by the values of correlation coefficients, both Pearson's correlation coefficient ( 0.12 for the average life expectancy, and in the case of the health indicator minus 0.35), and Spearman's rank correlation coefficient ( 0.08 for the average life expectancy, and in the case of the health indicator minus 0.37 ). In the cross section of provinces there was definitely greater diversification in terms of pharmaceutical consumption with the active

tion between types of medicines. In Poland, medicines are only refunded on a prescription from a list prepared by the Minister of Health. 


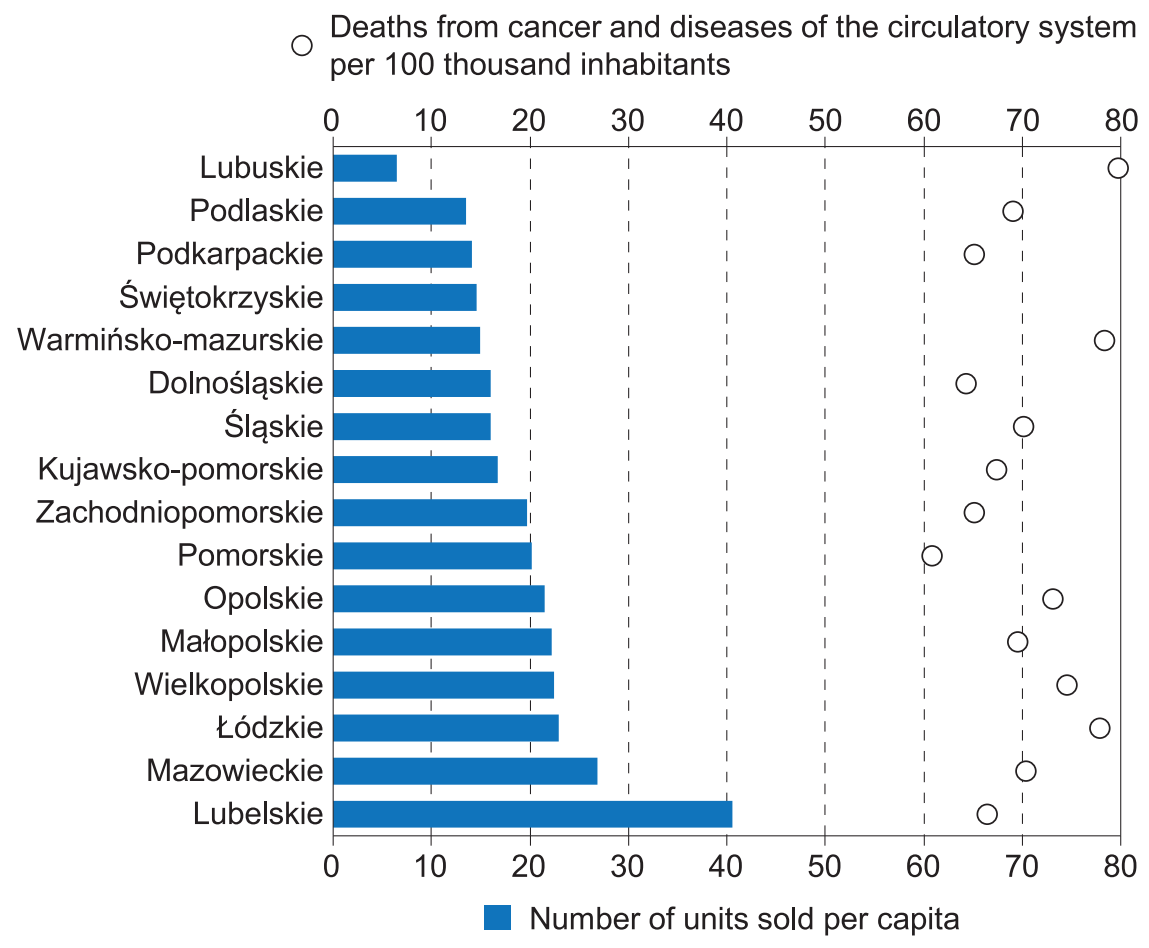

Figure 8. Quantitative account of vitamin C consumption versus health status by voivodships in 2016

Source: authors' own work based on data from the IMS HEALTH, GUS and Eurostat database.

substance ibuprofenum (the coefficient of variation was $28.4 \%$ and in terms of life expectancy the coefficient of variation was only $0.9 \%$ ) and in terms of intensity of deaths of major diseases civilization $(9.4 \%)$. The maximum volume of medicine consumption - 133 (lubelskie voivodeship) was almost 5 times higher than the minimum -27 units (lubuskie voivodeship), while the maximum life expectancy (małopolskie voivodeship) was only 3.6\% higher than the minimum (Łódź).

Similarly, as in the cross section of countries, when analyzing 2016 data by voivodships, we also did not find a significant relationship between the intake of ibuprofenum active medicine and the level of GDP per capita (Pearson's correlation coefficient was 0.12 and Spearman's correlation coefficient was 0.28$)^{2}{ }^{2}$

In light of the data on the consumption of the three selected pharmaceuticals, it turned out that in the cross section of voivodships there was a significant posi-

2 The source of data for the calculation of correlation coefficients in the cross section of provinces was the obtained base from the IMS (in the scope of medicines consumption) and the BDL database of the Central Statistical Office (GUS) (in terms of GDP per capita in PLN). 


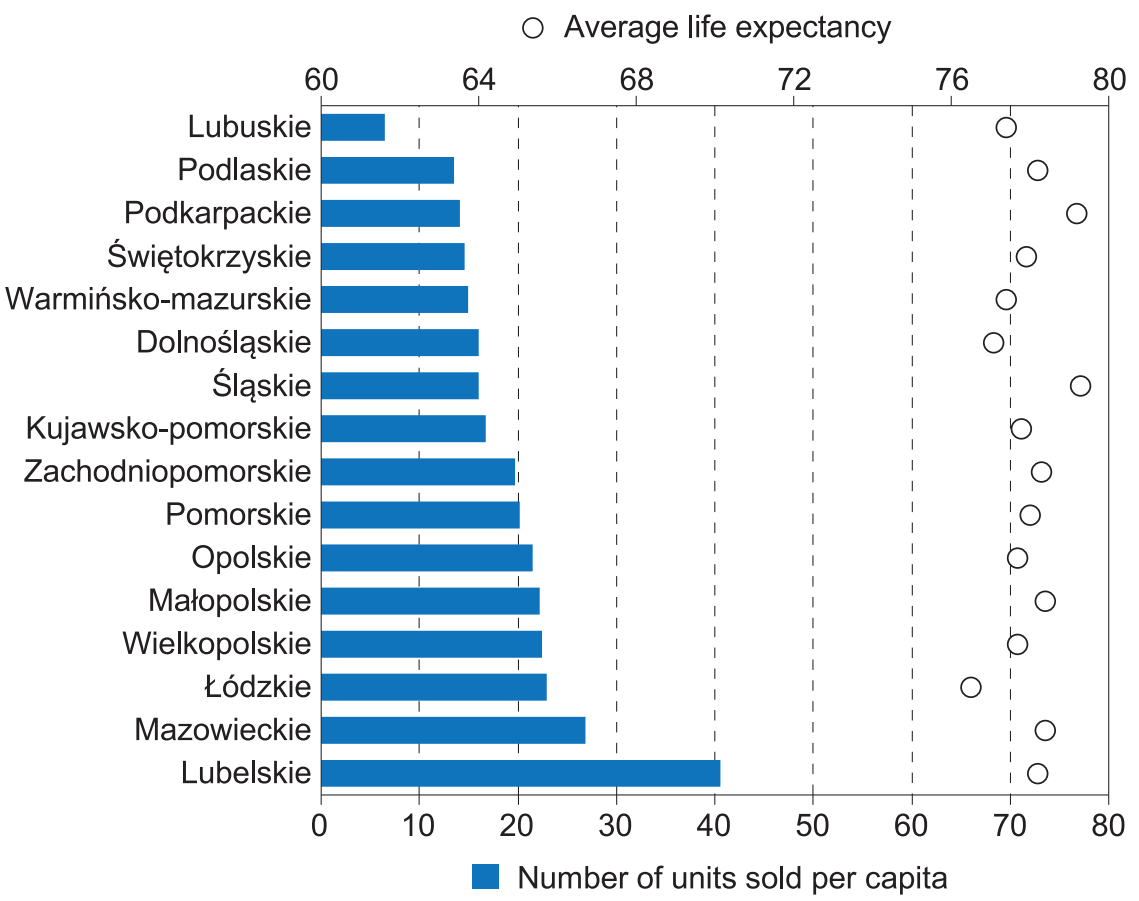

Figure 9. Quantitative account of vitamin C consumption versus life expectancy by voivodships in 2016

Source: authors' own work based on data from the IMS HEALTH, GUS and Eurostat database.

tive relationship between the consumption of vitamin $\mathrm{C}$ and the active substance ibuprofenum and between the consumption of vitamin $\mathrm{C}$ and magnesium with vitamin B6 (Pearson's correlation coefficient was 0.89 and 0.87).

Similarly, as in the case of the previously analyzed pharmaceutical with the active substance ibuprofenum, both the consumption of vitamin $\mathrm{C}$ and magnesium with vitamin B6 did not show dependence with selected indicators of health status (life expectancy and death rate due to civilization diseases) and socio-economic development (GDP). There was even greater variation in the spatial approach in the level of vitamin $\mathrm{C}$ and magnesium and vitamin B6 consumption (the coefficient of variation was $37.5 \%$ and $36.6 \%$, respectively). The maximum consumption of vitamin $\mathrm{C}$ in relation to the number of inhabitants - 40 units (lubelskie) was more than 6 times higher than the minimum size -6 units (lubuskie). In the case of the consumption of magnesium with vitamin $\mathrm{B}$, the disproportion between the maximum size - 35 units (lubelskie) and the minimum size of 6 units (lubuskie) was also significant — about 6 times (Fig. 7 and Fig. 8). 


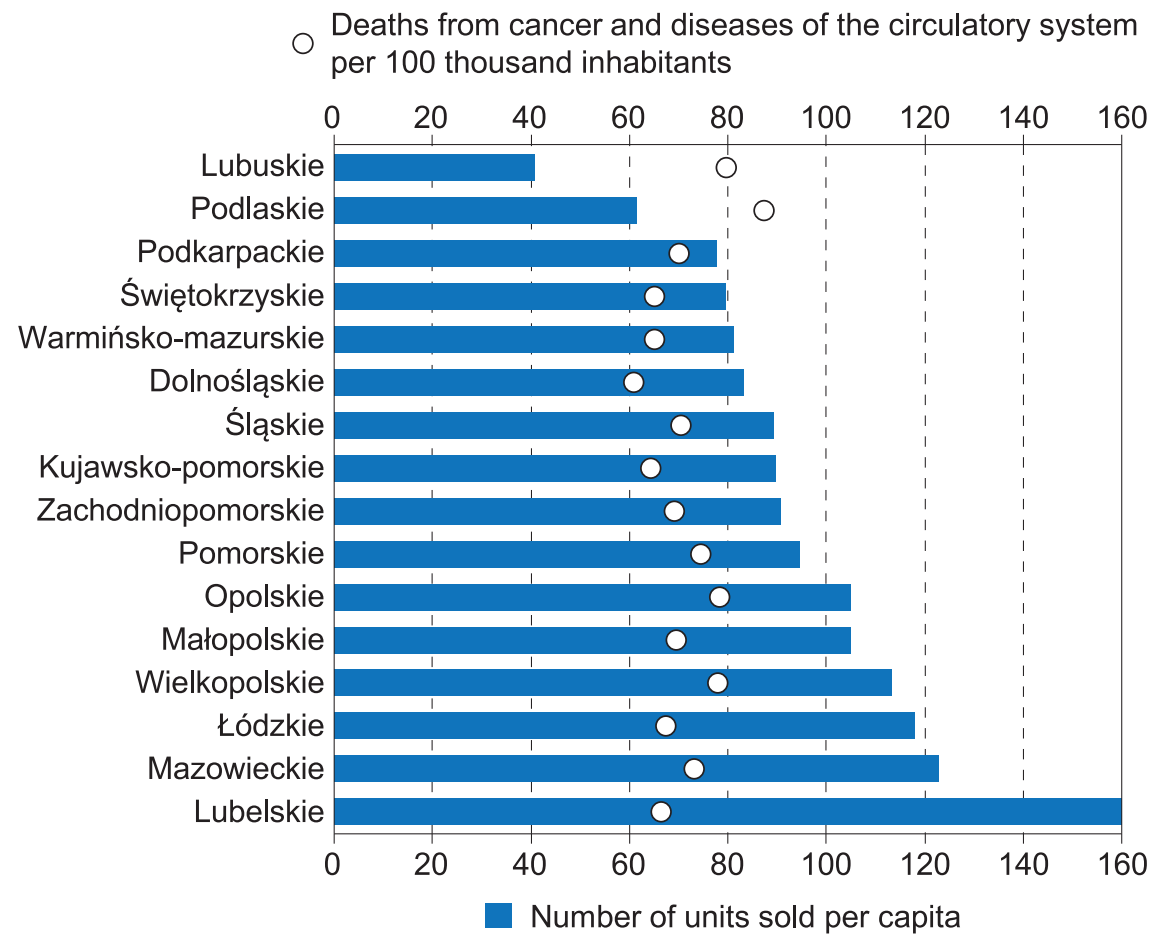

Figure 10. Quantitative view of magnesium with vitamin B6 consumption versus health status by voivodships in 2016

Source: authors' own work based on data from the IMS HEALTH, GUS and Eurostat database.

Pearson's correlation coefficient between vitamin C consumption and life expectancy, the intensity of deaths from cancer and cardiovascular disease, and the size of GDP per capita assumed small values, respectively: $0.06 ;-0.10$ and 0.21 (and Spearman's rank correlation coefficient respectively: $0.05 ;-0.28$ and 0.22 ).

Similar results were obtained by investigating the level of dependence between magnesium consumption with vitamin B6 and average life expectancy, the intensity of deaths from cancer and cardiovascular disease, and the size of GDP per capita - Pearson's correlation coefficient reached the values of $-0.04 ;-0.26$ and -0.12 (and Spearman's rank correlation coefficient respectively: $-0.26 ;-0.08$ and -0.18 ). 


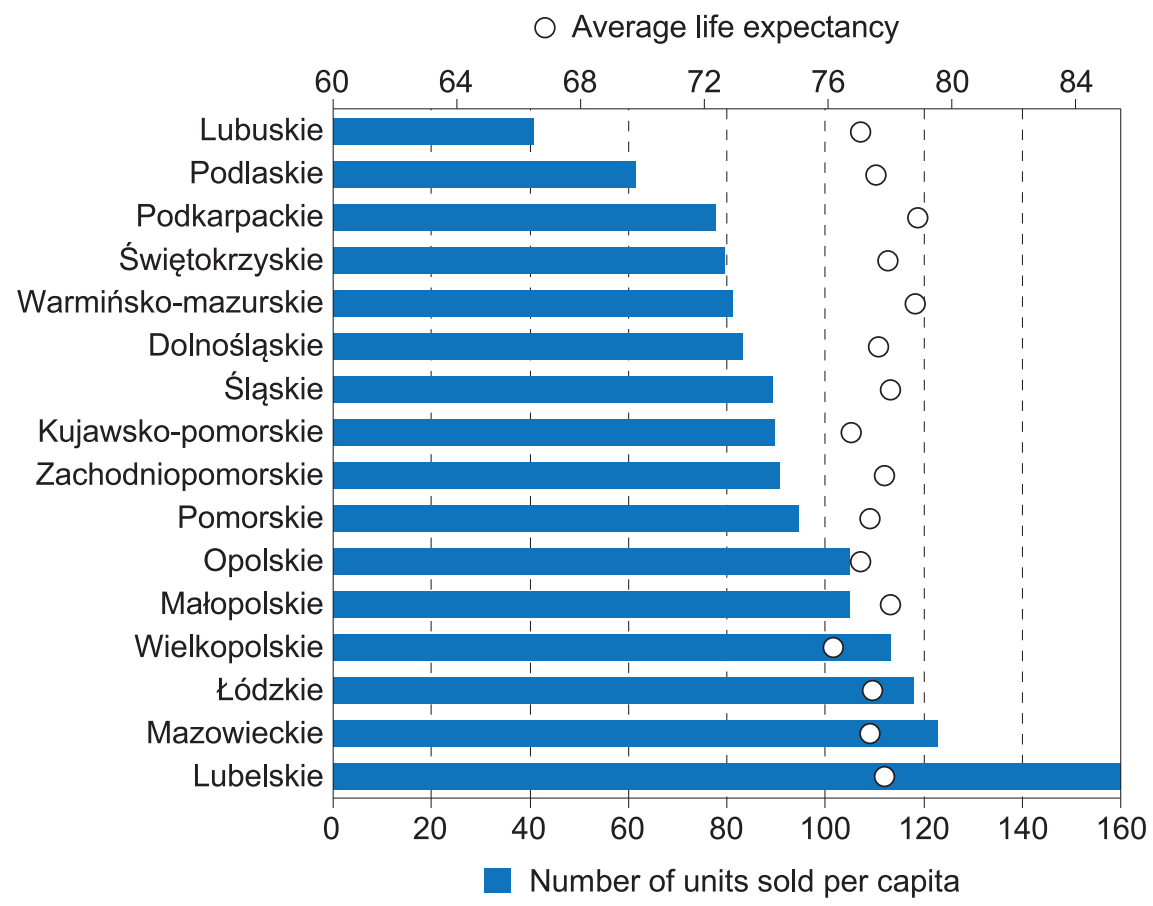

Figure 11. Quantitative view of magnesium with vitamin B6 consumption versus life expectancy by voivodships in 2016

Source: authors' own work based on data from the IMS HEALTH, GUS and Eurostat database.

\section{Conclusions}

Based on the analysis, it can be concluded that there is no relationship between the amount of medicines consumed, the duration of life and the indicator of social development (GDP per capita). The hypothesis was confirmed by the calculated Pearson correlation coefficients and Spearman's rank. Both in the international cross section and in the provinces, the consumption of medicines was characterized by a very large diversity. The international analysis showed that the highest consumption of medicines was noted in France, Greece and Poland, and the lowest - Mexico, Brazil, Japan and China. If we take into account the economic level and apply the GDP per capita comparison, we can conclude that France and Japan are characterized by similar GDP per capita, and the consumption of medicines in France is 4.5 times higher than in Japan. However, in both countries life expectancy is similar (82 French and 83 Japanese). In regional terms, for each of the three analyzed medicines, the highest consumption was recorded in the lubelskie voivodship, and the lowest in lubuskie. A small level of interregional differentiation occurred in the case of measures determining the state of health - average life expectancy and the intensity of deaths due to civilization diseases. 


\section{References}

Act of 6 September 2001, Pharmaceutical Law, Law Journal 2001, No. 126, item 1391.

Hepler, C., Strand, L. (1990). Opportunities and responsibilities in pharmaceutical care. American Journal of Hospital Pharmacy, 47(3), 533-543.

Kardas, P. (2010). Nieprzestrzeganie zaleceń terapeutycznych na świecie i w Polsce. In Polskiego pacjenta portret własny. Raport o przestrzeganiu zaleceń terapeutycznych przez polskich pacjentów [Polish patient's self-portrait. Report on compliance with therapeutic recommendations by Polish patients]. Fundacja Polpharmy na rzecz Wspierania Rozwoju Polskiej Farmacji i Medycyny [Polpharma Foundation for the Development of Polish Pharmacy and Medicine]. Warszawa: Pentor International.

Pharma Expert database. Retrieved September 1, 2018 from http://www.aptekarzpolski.pl/2016/11/ rynek-apteczny-w-pazdzierniku-2016.

Szalonka, K. (2014). Pożądane zachowania zdrowotne polskich gospodarstw domowych. Zeszyty Naukowe Polityki Europejskie, Finanse i Marketing, 12, 199-208. Retrieved September 1, 2018 from http://www.wne.sggw.pl/czasopisma/pdf/PEFIM_2014_T12_nr61.pdf.

Szalonka, K., Krajewska-Smardz, A. (2015). Rola marketingu w procesie wdrażania innowacyjnych produktów farmaceutycznych w Polsce. Logistyka, 2, 1077-1082.

\section{Internet sources}

Die Apotheke. Zahlen. Daten. Fakten. (2016). Retrieved September 1, 2018 from www.abda.de/ fileadmin/assets/Pressetermine/2016/TdA_2016/ABDA_ZDF_2016_Brosch.pdf.

Aptekarz Polski. (2019). Rynek apteczny w $201 \overline{8}$ roku wyżej niż rōk wcześniej (+4,8\%). Retrieved September 1, 2018 from www.aptekarzpolski.pl/2019/01/rynek-apteczny-w-2018-roku-wyzej-niz-rok-wczesniej-48/.

Central Intelligence Agency. Retrieved September 1, 2018 from www.cia.gov/library/publications/ the-world-factbook/.

Database - Eurostat. Retrieved September 1, 2018 from https://ec.europa.eu/eurostat/data/database.

Francja - PKB per capita. Retrieved September 1, 2018 from https://pl.tradingeconomics.com/ france/gdp-per-capita.

GUS - Bank Danych Lokalnych. Retrieved September 1, 2018 from https://bdl.stat.gov.pl.

Japonia - PKB per capita. Retrieved September 1, 2018 from https://pl.tradingeconomics.com/ japan/gdp-per-capita-ppp.

Nowelizacja ustawy - prawo farmaceutyczne (tzw. "apteka dla aptekarza"). (2017). Retrieved September 1, 2018 from https://www.nia.org.pl/2017/06/26/nowelizacja-ustawy-prawo-farmaceutyczne-tzw-apteka-dla-aptekarza/.

Polska - PKB per capita. Retrieved September 1, 2018 from https://pl.tradingeconomics.com/ poland/gdp-per-capita-ppp.

Ekonomia - Wroclaw Economic Review 25/4 (2019)

(C) for this edition by CNS 